\title{
POLITICS IN THE WESTERN MAYA REGION (II): EMBLEM GLYPHS
}

\author{
PÉTER BíRó \\ Abteilung für Altamerikanistik, Bonn
}

\begin{abstract}
RESUMEN: En una serie de artículos investigo el uso de varias palabras en las inscripciones mayas de la época Clásica de la Región Occidental que se conectan con lo que nosotros llamamos "política". Estas palabras expresan ideas y conceptos que ayudan a entender los matices de las relaciones entre las entidades políticas de las Tierras Bajas Mayas y su organización interna. En este artículo investigo el significado de los glifos emblema. Propongo que originalmente fueron topónimos y después llegaron a ser títulos de origen que indicaron descendencia común de un lugar original.
\end{abstract}

Palabras clave: Maya Clásico, epigrafía, vocabulario político, glifos emblema.

ABSTRACT: In a series of articles I reflect on the use of various expressions which are connected to what we call the political in the inscriptions of the Classic Maya Western Region. These words express ideas and concepts which help to understand the intricate details of the interactions between the political entities and their internal organisations in the Classic Maya Lowlands. In this article I investigate the meaning of emblem glyphs. I suggest that originally they were toponyms but later on they became titles of origin which indicated descendance from a common origin place.

KEYwords: Classic Maya, epigraphy, political vocabulary, emblem glyphs.

ReCEPCIÓN: 13 de abril del 2011. ACEPTACIón: 15 de junio del 2011. 



\title{
POLITICS IN THE WESTERN \\ MAYA REGION (II): EMBLEM GLYPHS
}

\author{
PÉTER BíRÓ \\ Abteilung für Altamerikanistik, Bonn
}

\section{Introduction}

Emblem glyphs were and are a ubiquitous element of Classic Maya inscriptions and from their discovery they remained in the centre of the debate about Classic Maya political organisation and politics in general (Berlin, 1958). As the general identity of the emblem glyphs is debated I present several emblem glyph main signs which function as other toponyms, and therefore I suggest that emblem glyph main signs in the majority of the cases (where data is available) were once toponyms; it is a different matter, though, what kind of toponyms they were (referring to one building, one area of a site, a site, a region, or mythical places).

Later on, I present a hypothesis about emblem glyph main signs where I argue that they are places of origin for all titled individuals who claimed descent from a given family and they reflect real or fictive blood connections. Their reference to territory was not that important and they were shifting on the political landscape with the migrations of the families who used them.

\section{Historical Antecedents}

Heinrich Berlin (1958) identified emblem glyphs in Classic Period inscriptions when he discovered that they were emblematic to particular sites. In his original paper Berlin did not argue for any meaning specifically, but he suggested three probabilities: name of the city, the name(s) of the patron deit(ies) of a particular city, or the name of the ruling dynasty of the city.

I began this paper in 2009 at La Trobe University, Australia, and then I continue the article at the Institut fuir Altamerikanistik at Bonn, Germany. In Australia I received funding from a La Trobe University Postgraduate Research Scholarship and also from an International Postgraduate Research Scholarship, while in Germany my stay is financed by the Humboldt Stiftung. I would like to thank Peter Mathews for his help during my stay in Melbourne. I cannot thank enough the kind offer of Nikolai Grube to work in Bonn. My research benefited from ideas of many colleagues such as Dmitri Beliaev, Alexander Safronov, Albert Davletshin, Guido Krempel, Christian Prager, Barbara MacLeod and Elisabeth Wagner. I thank my partner Doorshysingh Jugessur for reading the manuscript and correcting it with his insights. 
Researchers after Berlin discussed these three suggestions but they did not propose any new interpretation. Proskouriakoff (1960: 471) "inclined to think that it refers to lineage or dynasty rather than to place", while Barthel suggested that it "seems to concern place-names as well as ethnic names" (Barthel, 1968: 120, qtd. in Mathews, 1991 [1996]: 22). Marcus (1973: 913) argued that emblem glyph refers to "the site, as well as the territory subject to it". Kelley, however, argued that the main signs of emblem glyphs are place names (Kelley, 1976: 215). Later on Mathews and Justeson (1984: 216) maintained that the main sign refers to "the political unit over which one site held dominion". ${ }^{1}$ Mathews' (1991 [1996]: 26) later opinion was that emblem glyph main signs referred to the city itself and the territory subject to it.

Simon Martin and Nikolai Grube (1994) accepted that emblem glyph main signs are toponyms referring to the polity of a given archaeological site where they occur. Stuart and Houston (1994: 2-7) identified place names in the inscriptions which were different from known emblem glyphs and they concluded that emblem glyphs stand for the name of Classic Maya states and the royal seats have their proper names. Following suit, most epigraphers accepted that there is a difference between an actual place name and the main sign of emblem glyphs and this understanding was phrased in the book of Linda Schele and Peter Mathews (1998: 23) for the wider audience such as "emblem glyphs named the kingdoms that dotted the political landscape, and within these kingdoms there were locations identified by place names".

This same conceptualisation of emblem glyph main signs remained in the book of Simon Martin and Nikolai Grube (2000: 17) where they maintained that the main signs referred to the name of a particular kingdom or polity. In a discussion about the political geography of Southern Campeche Nikolai Grube (2005: 98) discussed a difference between emblem glyphs and "toponymic titles" reviving a previous idea of Stephen Houston (1986) about "problematic emblem glyphs".

Erik Boot (2005: 383-384) thinks that emblem glyph main signs were indeed place names but he has not specified his ideas this further. He identified at least one emblem glyph main sign with not a particular kingdom or site but with one particular region (Boot, 2005: 511). Recently Simon Martin (2005: 12) has dealt with emblem glyph main signs and tentatively concluded that "in essence, these emblem names seem to label royal houses whose connections to specific territories are less intrinsic than habitual".

Alexander Tokovinine has been arguing that emblem glyphs are "places of origin" and they refer to a smaller entity than the city itself (personal communication, 2007). He mentioned the specific example of Naranjo where he sug-

\footnotetext{
1 "Emblem Glyphs...[were] functioning as royal titles (they invariably occur in royal name phrases).... The 'divine' interpretation of the prefix is still far from proven but is viewed favourably by many epigraphers. The main sign is viewed by most epigraphers as a place-name, referring either to the city itself or to the territory that it controlled or to both. And the 'lord' is precisely the title that we would expect to find in a royal name phrase." (Mathews, 1991 [1996]: 25).
} 
gested that the toponym referring to the C-9 Triadic Group was wak ik' ? nal pek sa'al and it was the original place of the Naranjo ruling family (Tokovinine and Fialko, 2007). Also, he proposed that in the region of Southern Campeche emblem glyphs and toponymic titles refer to different localities, and a triadic pattern emerged where Chik Nahb' referred to Calakmul and Ux Te' Tun to a wider region, thus emblem glyphs would be shifting entities less connected to territories (Tokovinine, 2007a and b; see Grube, 2005).

These evolving ideas can be helpful to discuss both emblem glyphs and toponymic titles in the Western Maya region and they can be fruitful for the interpretation of various cases of concerning the use of toponyms.

Emblem glyphs as defined by Heinrich Berlin (1958) contained a fixed element later deciphered as the derived adjective k'uhul 'divine, sacred, k'uh-like' (Ringle, 1988; Stuart, 1995). However, Stephen Houston (1986) drew attention to the existence of titles which were alike to emblem glyphs but in one exception namely did not contain the k'uhul adjective. Also, he first noted that there is a chronological component in the use and form of emblem glyphs according to which the $k^{\prime}$ uhul adjective appears from the $9^{\text {th }} b^{\prime}$ aktun (Houston, 1986: 1). Later he and David Stuart (1996: 295; 2001: 60) argued that the appearance of the $k$ 'uhul adjective reflected a wish to differentiate and accentuate an existing hierarchy between the royal families and a "burgeoning group of nobles, many of royal descent".

The question then is not only what emblem glyph main signs were referred to, but how their reference(s) changed through time losing some connotations and accruing others. Another question is whether there was any difference among the main signs of emblem glyphs and the main signs in toponymic titles. Indeed, Nikolai Grube (2005: 98-99) proposed that sites whose rulers used toponymic titles originated as "dependencies or even colonies of more potent centres, which used full emblem glyphs" implying a different historical process from that delineated by Stephen Houston and David Stuart.

\section{On Toponyms}

David Stuart and Stephen Houston (1994) identified toponyms-which can include once actually existing place names on the landscape, mythological places, building names and possibly names of regions-in Classic Period inscriptions. This seminal discovery is based on the decipherment of the root intransitive verb uhti 'occur, come to pass' by David Stuart (1990), the identification of the chan/ $k a b$ '-ch'e'n '[inhabited] place' difrasismo and their structural identification of the "place name formula" (Stuart and Houston, 1994: 7-18). The place name formula is a basic locative sentence composed of the root intransitive verb uhti/uhtiiy, a toponym and the chan/kab'-ch'e'n expressions. ${ }^{2}$

2 "We can readily identify many place glyphs...the actual place names of well-known sites...For 
Additionally, they listed other verbs with which place glyphs stand frequently such as $m u[h] k a j$, patlaj, huli, puluy, hub'uy etc. and they were able to identify titles of origin with the agentive prefix aj-, mythological place names, site areas and building names (Stuart and Houston, 1994: 43-91).

Although they did not deny the geographical connotations of emblem glyph main signs, they did not propose what was their scope, i.e. regions, polity names, site names or other geographical features such as lakes, swamps, hills etc. Also, they emphasised the differences between emblem glyphs and place names occurring in the inscriptions of the same site (Stuart and Houston, 1994: 7). In the following I examine several emblem glyph main signs from the Western Maya Region and from the Southern Maya Lowlands to show that they function like other toponyms - they follow the same verb, they are chan-ch'e'n and they stand (occasionally) with the agentive prefix $a j-$.

\section{Comalcalco}

There are at least two emblem glyphs mentioned in the inscriptions of the westernmost Classic Maya site: JOY-CHAN-AJAW (figure 1a) and K'UH-B'AK-la-AJAW (figure 1b). The first one appears on a brick (Peter Mathews, personal communication, 2007) and is mentioned on Tortuguero Monuments 6 and 8. Joy chan ajaw is written without the k'uhul adjective, and there is not a single example when it occurs in the toponymic formula. However, on Tortuguero Monument 8, Glyph 43 (figure 2) it appears in the clause 'STAR-WAR'-KAB'-AJ-JOY-CHAN-na or ?-kab' aj joy chan "got ?-ed the land [of] the one from Joy Chan". This is a very frequent formula with this verb, but the interesting thing here is that the joy chan is standing with the agentive prefix $a j-$.

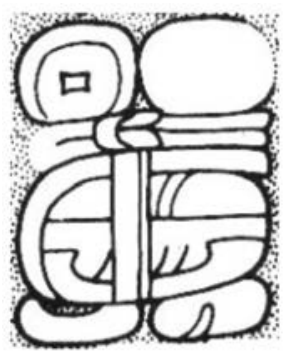

a

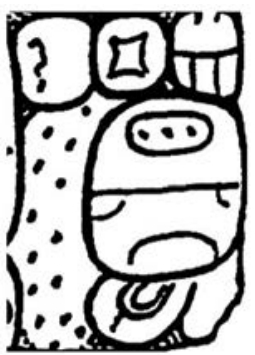

$b$

FIGURE 1. JOY-CHAN-AJAW-wa, Tortuguero Monument 6, drawing by Ian Graham (Grube, Martin and Zender 2002:II-29) and K'UH-B'AK-AJAW-wa, Comalcalco Brick 2,

drawing by Anonymous (Grube, Martin and Zender 2002: II-42)

the most part these place glyphs are distinct from the Emblem Glyphs, although there are some exceptions...". (Stuart and Houston, 1994: 19; my emphasis). 


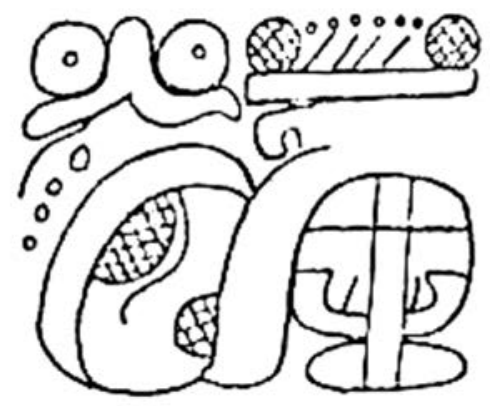

Figure 2. Tortuguero Monument 8

(Glyph 43, drawing courtesy of Berthold Riese)
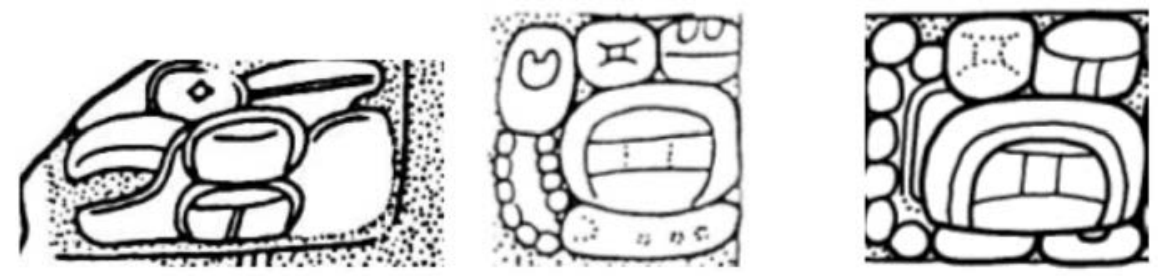

FIGURE 3. po-po-o, po-o and po

Firt two drawings by Ian Graham (CMHI 6: 135; 6: 160) and the third by Simon Martin, 2004: 72

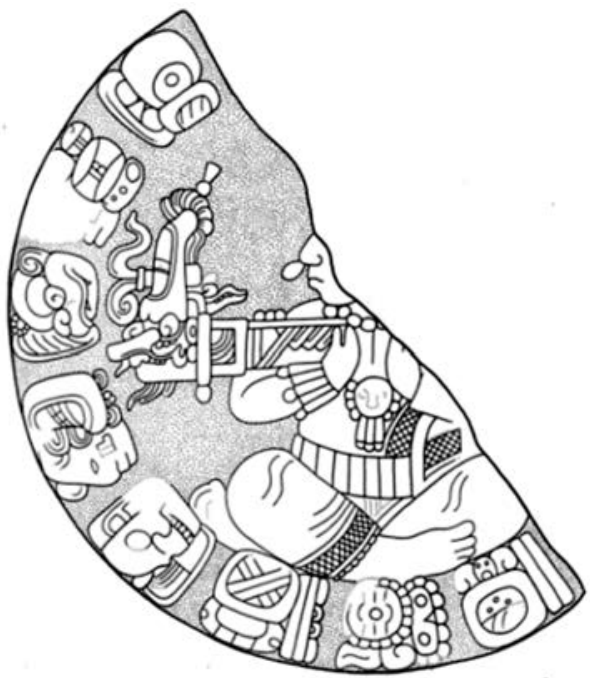

Figure 4. Tonina Monument 144.

Drawing by David Stuart (Grube, Martin and Zender, 2002: II-41) 


\section{Tonina}

In this site there is one single emblem glyph which is written as po-po-o, po-o or po (figure 3). The earliest monuments use the emblem glyph with the title ajaw but without the k'uhul adjective, which appears first on the unprovenanced Emiliano Zapata Panel (figure 5), dated 9.7.19.0.0 (592). It stands also with the feminine marker IX $\sim i x$ on Monument 144 (figure 4) dated 9.14.10.8.14 (722). The complete form of the emblem glyph is usually transcribed as popo', however various epigraphers suggested that on Chinikiha Throne 1 (figure 6) the sequence po'-a-NAL was referring to Tonina. This possibility is strengthened by the text of one undated and fragmentary monument from Tonina where the name of the site is written as YAX-ji wi-tzi po-o-a (Monument 126, figure 7). ${ }^{3}$ Both forms can help to reconstruct the complete place name as po-po-o-a or popo'a.

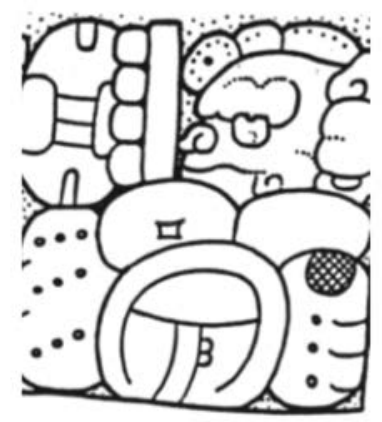

Figure 5. Emiliano Zapata Panel.

Drawing by Nikolai Grube (Grube, Martin and Zender, 2002: II-13)

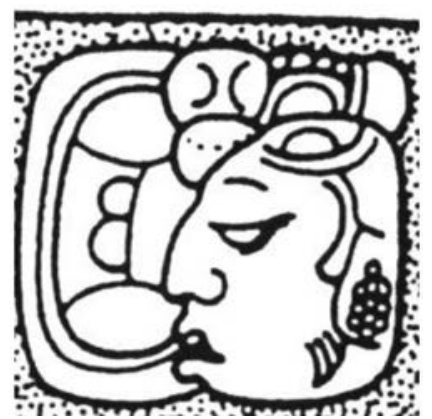

FIGURE 6. po-a-NAL.

Chinikiha Throne 1, drawing by Ian Graham (Grube, Martin and Zender, 2002: II-12)

\footnotetext{
${ }^{3}$ Recently, Erik Boot (2005: 190, note 43) has reinterpreted the various -a endings on place names and suggested that in certain cases it does not cue an underrepresented - $/ h] a^{\prime} \sim$ 'water' noun but a toponymic suffix $-a$ ' with the hypothetical meaning 'territory'. The -nal suffix on the Chinikiha throne example should not be confused with the frequent toponymic suffix -nal (T84/86+851) 'place'.
} 


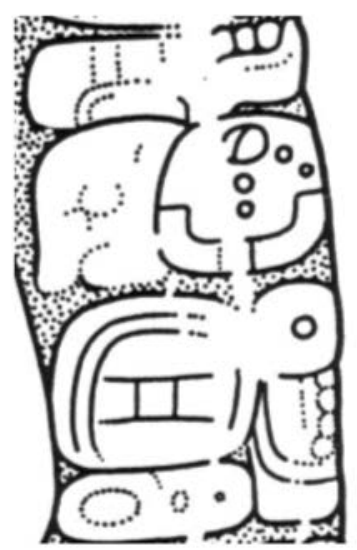

Figure 7. YAX-ji-wi-tzi po-o-a

(Tonina Monument 126, drawing by lan Graham-СмнI 6: 155)

In the case of Tonina there is no doubt that the emblem glyph main sign was a toponym; however its reference is not clear. If Erik Boot's suggestion is valid, then it could refer to the territory of popo', but it is not clear whether this last term refers to the city or to the people (ethnonym po uinicob as was suggested by Maricela Ayala, 1995). In case of a popo' $[h] a^{\prime}$ reconstruction this would refer to a river or stream, a frequent element of toponyms in the Postclassic Yukatek area. Tonina lies in the valley of the Ocosingo River which could have been called Popo'ha' during the Classic Period which in fact could have been turned into a place name for the site. This would be not a unique example as various other toponyms can be explained by the transposition of a river or stream name close to the site.
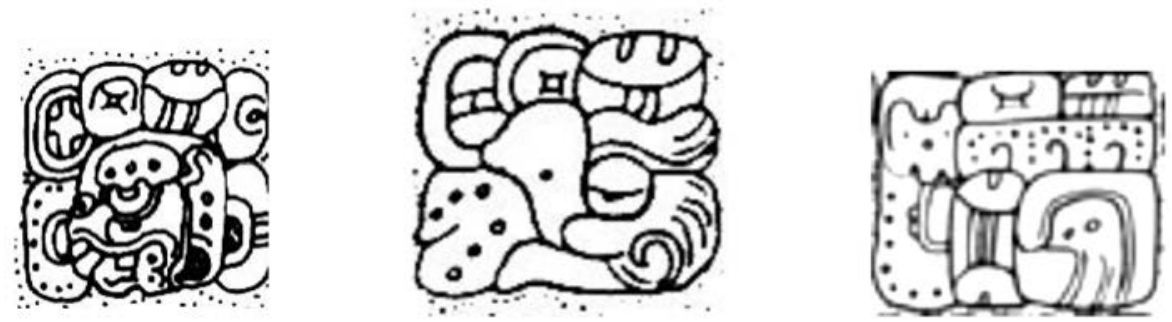

Figure 8. B'AK, MAT and to-ko-TAN as main signs of Palenque Emblem Glyphs. Drawings by Linda Schele and Peter Mathews (FAMSI LS Archive and Mesoweb)

Rather, this variant of the head of the Maize God is cuing a noun with the meaning 'native', person from, as was first suggested by Linda Schele and Nikolai Grube (1994: 104, 131; Guenter, 2003: 9; Boot, 2005: 190, note 43). 


\section{Palenque}

There are at least three full emblem glyphs in the site and one frequently mentioned toponym whose relations to persons, supernatural beings, and site areas are not fully understood. The three emblem glyphs are K'UH-B'AK-la-AJAW, or K'UH-B'AK-AJAW; K'UH-MAT-la or K'UH-MAT-AJAW; and K'UH-to-ko-TAN-na-AJAW (figure 8). The toponym is spelled LAKAM-HA' as was deciphered by David Stuart (Stuart and Houston, 1994: 30-31; figure 9). The transcriptions and translations of the last toponym are straightforward: lakam ha' 'big water'. Its use is restricted to the Cross Group Inscriptions, Temple XVIII, XIX, XXI and the Palace Group and it is very likely that once it referred to the Otolum River and the restricted centre of the site where the royal dynasty was resided from the early $6^{\text {th }}$ century.

Interestingly, Lakam Ha' never stands with ajaw, winik, sajal or any other title, however it follows verbs such as huli, uhti and pat, and several times it precedes the chan-ch'e'n difrasismo. Also, except for a record in Bonampak, which can refer to a different site (Stuart and Houston, 1994: 31), it does not stand with the agentive prefix $a j$ - or with the female prefix $i x$-. Indeed, it is restricted to Palenque inscriptions (except the dubious Bonampak Lintel 4 example).

From the other three full emblem glyphs, the interpretation and reference of MAT-la is less obscure now due to the work of many epigraphers (see Stuart, 2005). The relationship between the MAT-la main sign and the mythological toponym MAT-la, ma-MAT-wi-la, ma-ta-wi and ma-ta-wi-la on the one hand, and the MAT and ma-ta sequence in the pre-accession name of several royal members is ambiguous. On the other hand it is not impossible that they are all related indicating a shared and imaginative identity with the supernatural beings who were the dwellers of the specific place called mat(V)wil (this transcription was suggested by Lacadena and Wichmann, n.d.: 19). That ma-ta-wi-la was a toponym is proven by its co-occurrence with the root intransitive uhti in several inscriptions. Also, it is not at all unique that Classic Maya rulers used a mythological place name as their emblem glyph. A similar scribal habit is attested in Naranjo whose

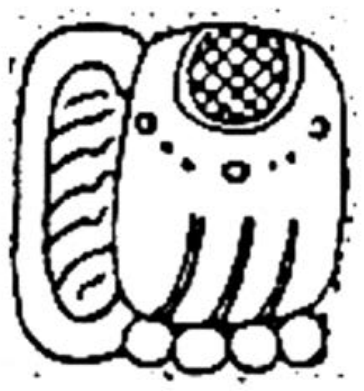

FIGURE 9. LAKAM-HA'.

Drawing by Linda Schele (FAMSI LS Archive) 
rulers from the Early Classic period used the term wak kab' nal winik where wak kab' nal was probably one of a set of mythological locales mentioned on ceramics (Martin, 1996: 4; Tokovinine and Fialko, 2007: 3, note 3).

The second emblem glyph, to-ko-TAN-na or tokta/h/n 'cloud centre', which is the most restricted, is attested with the k'uhul adjective, with ajaw, winik and ch'ok titles, and it stands with the verb uhti. Its records come from texts almost 200 years later than the events recounted: the accession of K'uk' B'ahlam I in 431 (692), period-ending ceremony at Toktahn in 435 (692), accessions of secondary nobles in 445 and 460 under the supervision of Ch'a-? k'uhul tokta/h/n ajaw (after 761), deity-supporting ceremony (okte'el) in 496 occurring in tokta/h/n (692). In one contemporary mention (ch'ok tokta/h/n winik) it refers either to Ix Tz'akb'u Ajaw or K'an Joy Chitam II on the Palace Tablet dedicated in 722.

The location of Toktahn was imagined to be both inside and outside of Palenque. Some suggested that it referred to the valley from which the Otolum River flows (Schele and Mathews, 1998: 95) while others opted for the Picota area (Barnhart, 1999). At present there is not enough inscriptional evidence to decide between these proposals, however a change happened between the use of these two emblem glyph main signs, tokta/h/n and b'ak/VII, and not between b'ak/VJl and lakam ha'.

The third emblem glyph is written B'AK-la or simply B'AK, making it difficult to reconstruct the underspelled vowel(s) (Lacadena and Wichmann, n.d.: 27). Although Stuart and Houston (1994: 30-31) never mentioned it, after their identification of the Lakam Ha' toponym most authors accepted that this main sign is a geographical location and refers to the polity of Palenque (see Schele and Mathews, 1998: 23, 95). Though its translation is in doubt, it is clear that it contains a -Vl toponymic suffix with the meaning 'place' and some suggested that it can be translated as the "Place where the Heron Abounds" (Lacadena and Wichmann, n.d.: 28).

The real problem is to know exactly what this place name referred to, or how its reference evolved through time. The inscriptions of Palenque, although the longest ones in the whole Maya Lowlands, cover a short time period, approximately from 649 to 799, or only 150 years. Retrospective information abounds ranging from mythological events deep in the past (Schele and Freidel, 1990: 217-261; Stuart, 2005) to early historical deeds of former rulers schematically narrated to serve as template to current successors. The investigated and excavated parts of the site are basically creation of late rulers such as K'ihnich Janab'nal Pakal, Kan B'ahlam II, K'an Joy Chitam II, K’ihnich Ahkul Mo' Nahb' III, Upakal K'inich, Kan B'ahlam III and K'uk' B'ahlam III, and a retrospective history of 184 years is known only from later inscriptions.

There are two mentions of the b'ak(V)l main sign as toponym, both of them coming from inscriptions outside of Palenque, and this can be an important clue to its reference. The first is on Tortuguero Monument 6 (E2-F2) where it happens to be in a very interesting context. After the narration of war campaigns, and three 
years after his accession, B'ahlam Ajaw was the main actor in an undeciphered event, the re-enactment of a similar event in 353 which the text emphasises to have happened in B'AK-la (figure 10):

\section{UH-ti-ya TAN-HA'-B'AK-la \\ uhtiy talh/n ha' b'ak(V)l \\ "it happened in/in front of the water (of?) B'ak(V)l"}

In this short clause both the intransitive verb uhti and the locative preposition $t a[h] n h a^{\prime}$ indicate that $b^{\prime} a k(V) l$ was a concrete place, not just a vague reference to the domain of the Palenque rulers. As a translation I put "in the water" and "in front of the water". I think both translations are possible, and the same expression occurs several times in the inscriptions of Yaxchilan in front of the pa'chan toponym where the big horseshoe bend of the Usumacinta river makes either "in the middle of the water" or "in front of the water" plausible (Martin, 2004a: 2). The parallel construction $t a[h] n$ ch'e' $n$ ? clearly makes $t a / h / n h a$ ' a good indicator of place names (Stuart, 2003: 1-2). The ruins of Palenque lie among several small rivers, among them are the Otolum and the Picota. A descriptive term ta/h $/ n$ ha' $b^{\prime} a k(V) l \sim$ "in the middle of the water/rivers where the herons? abounds" fits the geographic situation of the site.

The second record of B'AK-la is on Morales Stela 4 (figure 11) where it follows the third coronation of Muwan? Jol Pakal? (Martin, 2003). The text again is quite explicit:

\section{yi-chi-NAL K'INICH-KAN-B'ALAM u-ti-ya B'AK-la}

yichnal k'ilh]nich kan b'alh]lam ulh/tiy b'ak(V)l

"in the presence of K'ihnich Kan B'ahlam it happened [at] B'ak(V)l"

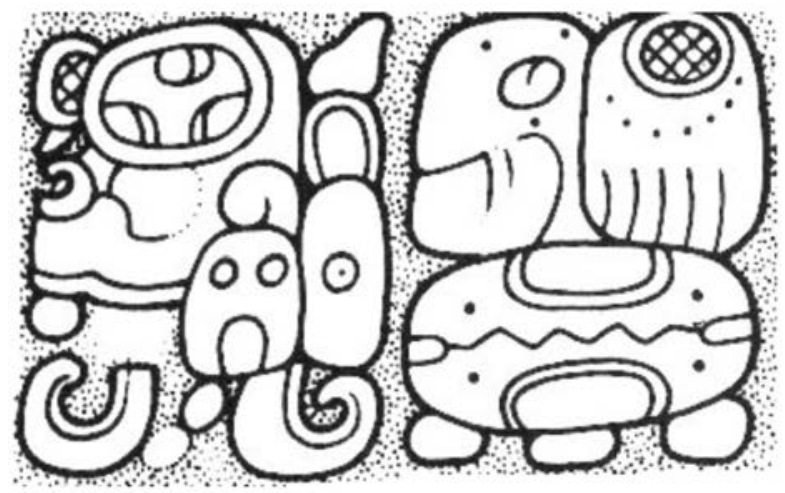

FiguRE 10. UH-ti-ya TAN-HA'-B'AK-la.

Tortuguero Monument 6, E2-F2; drawing by Ian Graham (Grube, Martin and Zender, 2002: II-29) 


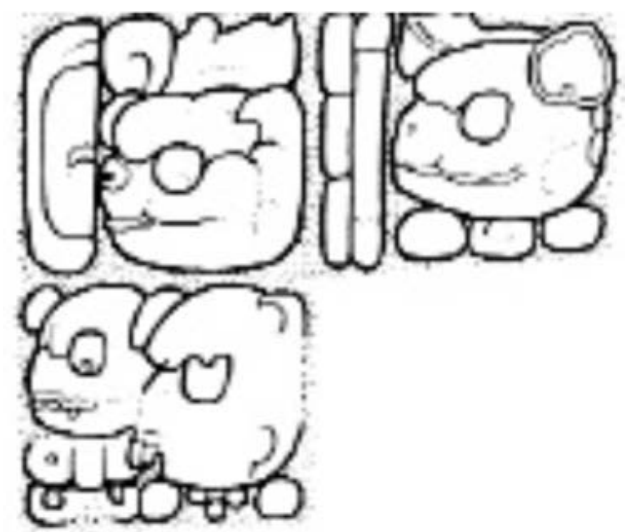

Figure 11. yi-chi-NAL K'INICH-KAN-B'ALAM u-ti-ya B'AK-la, Morales Stela 4, E6-E7; drawing by Simon Martin (Martinm, 2003: 45)

In this clause the subordinate ruler presumably wanted to emphasise the exact place of his accession, and it is totally improbable that he just indicated in a vague reference that the event happened somewhere in the polity which was called B'ak(V)l. Therefore this text states the accession was undertaken in the presence of the Palenque ruler, and most probably the toponymic reference is there to indicate the exact location of the event, that is, in the seat of Kan B'ahlam II, in Palenque.

Tortuguero Monument 6 and Morales Stela 4 were dedicated in the second half of the $7^{\text {th }}$ century hinting that at least during this period of time the elite from a wider region referred to Palenque as $b^{\prime} a k(V) l$. The royal family of Tortuguero claimed the Palenque emblem glyph but probably never used it for Tortuguero itself, which was rather called K'ahk' Witz or 'Fire Mountain', a possible reference to the majestic Macuspana volcano behind the site. ${ }^{4}$

Palenque's geographical location on a plateau criss-crossed by several rivers and streams such as Picota, Motiepa, Otolum, Piedras Bolas etc. (see Barnhart, 2007) makes it possible that different internal areas of the site were named close to the rivers. An example is Lakam Ha', a reference to the most important river within the site (and to the surrounding area), which was the royal precinct from the $5^{\text {th }}$ century. Thus B'ak(V)l could have referred to the plateau, or originally to the first settlement on the plateau. The location of Toktahn is completely speculative and without new inscriptions it remains so. It is equally possible that it

\footnotetext{
${ }^{4}$ This situation is very similar to the formerly confusing relations between Tikal and Dos Pilas. Nowadays, due to the discovery of new texts from the latter site it is known that a dynastic split happened but this did not annul the right to use an emblem glyph whose main sign was always referring to the greater site of Tikal, or some specific locale within it (Stuart and Houston, 1994: 19, 84-92; Boot, 2002; Guenter, 2003).
} 
was outside of the area designated as $\mathrm{B}^{\prime} \mathrm{ak}(\mathrm{V}) \mathrm{l}$ or the plateau, however it is more plausible that it was some earlier plaza centre within the site, especially because rulers were active in both Toktahn and Lakam Ha' according to retrospective inscription: Butz'aj Sak Chik was probably returning back to Lakam Ha' in 490 while K'an Joy Chitam I was participating in an okte'el ritual in Toktahn in 496. It is thus more probable that the two places were close enough to each other and movement was possibly back and forth, even for a six-year-old child.

Palenque certainly had inner divisions, which are much more apparent in other sites, as has been attested by both epigraphic and settlement pattern studies (Dos Pilas, Tikal, Copan-see Stuart and Houston, 1994; Wagner, 2005). Guillermo Bernal Romero and Benito Jesús Venegas Durán (2005) suggested a division of at least twelve familiar compounds in Palenque during the Late Classic Period. Although this proposal is based on an incorrect decipherment of the names of a group of deities as designation of the Palenque royal family (b'alun chan yon?/ yok'in? waklajun on?/yokin? b'alun tz'akb'u ajaw), Palenque had other toponyms mentioned in the inscriptions, most of them referring to buildings while others probably to parts of the site.

The inhabitants of Group IV may refer to themselves as aj sik'ab' and though it is possible that this is a title, or refers to a site outside of Palenque, it is equally conceivable that once it was the name of the area where the group was situated. Also, David Stuart and Stephen Houston (1994: 84) identified the toponym Yehmal K'uk' Lakam Witz or 'Descending Quetzal Big Hill' which probably referred to the 'large hill looming behind the Cross Group'. Indeed, this particular toponym behaves syntactically as many other which directly precede another toponym which usually occurs alone: ye/h/mal k'uk' lakam witz lakam ha' chan ch'e'n (Temple 18 Doorjamb D17-19).

Similar constructions exist in inscriptions from Dos Pilas, Tikal, Naranjo, El Cayo and Copan (figure 12):

K'IN-NAL-HA' ?-HA' (Dos Pilas Stela 8 H6-I6)

9-TZ'AKB'U-?-NAL CHAN-CH'EN MUT-la (Tikal Stela 31 H21-G24)

6-IK' ? HUN-NAL pe-ke SA'-li (Naranjo Stela 24 B8-B9)

TAN-na-CH'EN-na YAX-a-ku la-HA' YAX-ni-la (El Cayo Altar 4 l'3-J'4)

UH-ti-ya ?-pi-CHAN-na CH'EN-na 3-wi-ni-ti-ki (Copan Stela 10 C9-D10)

u-ti-ya 3-TE'-TUN-ni-chi-ku-NAB' (La Corona Ball Player Panel 1 F3-F4)

However difficult the interpretation of these longer sequences, it is more probable that they contain at least two different toponyms althougb they are similarly conceptualised as proven by the term chan-ch'e'n. Sometimes they were interpreted as full names of a site, however this is unlikely as their use is much more frequent separately and one toponym is always more widely used than the other. In cases of Tikal, Naranjo and Copan one toponym serves as the main sign of the emblem glyph, and most probably in El Cayo, Palenque and Dos Pilas the 

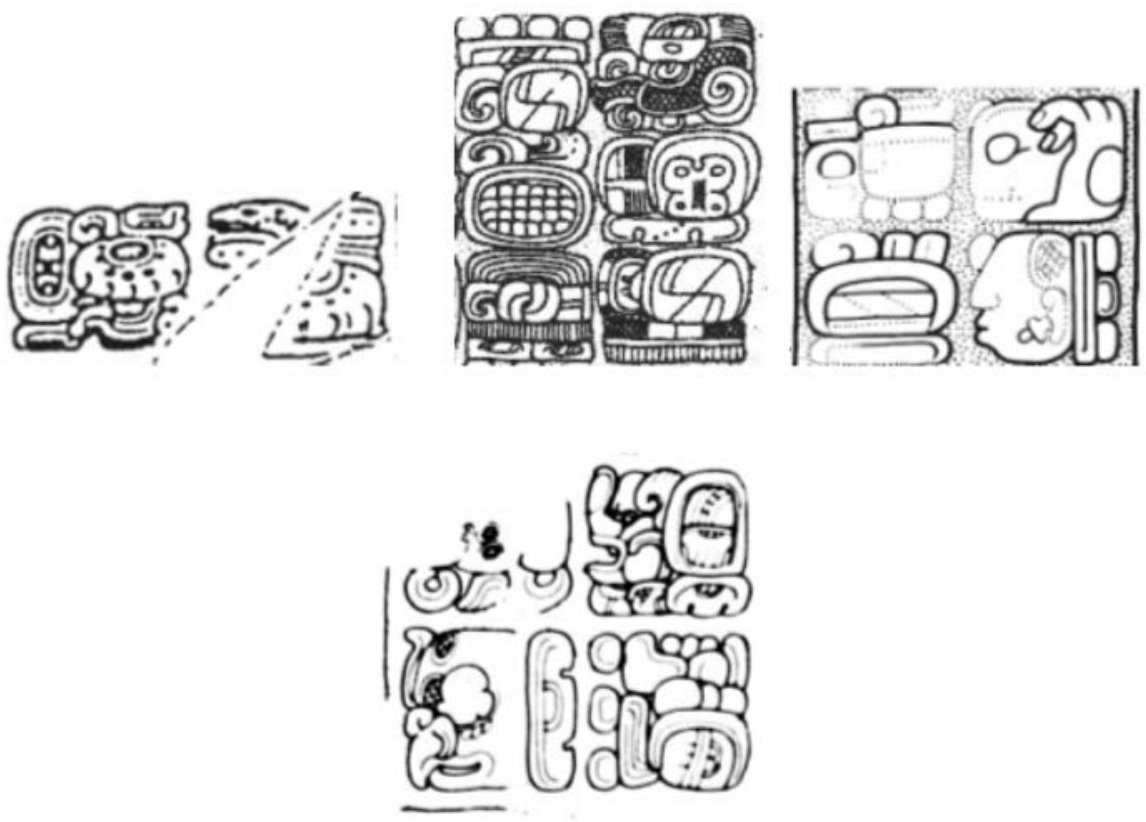

Figure 12. Toponym Incorporation.

Drawings by Ian Graham (Houston 1993: 111); by Linda Schele (FAMSI LS Archive); by Ian Graham (Смн 2: 64); and by Linda Schele (FAMSI LS Archive)

later toponym (Yax Nil, Lakam Ha' and ?-Ha') are referring to a wider area than the syntactically preceding toponym. Nevertheless this is not a rule as the cases of Calakmul and Copan show: both Ux Te' Tun and ?-pi are referring to a wider area than Chik Nahb' and Ux Witik, respectively.

As a conclusion, I suggest that B'ak(V)I was not the name of the Palenque polity but the origin place of a royal family who had given rulers to Palenque, Tortuguero and later to Comalcalco. The Palenque emblem glyph main sign is a par excellence toponym most probably referring to the river-crossed high plateau on which the archaeological site was built. Lakam Ha' could have referred originally to the Otolum River, while Toktahn could have been an earlier part of the site. Mat(V)wil was a mythological toponym which was appropriated by one branch of the royal family seated in Palenque. It is very difficult to know whether B'ak(V)l ever referred to a wider area and this cautions epigraphers against interpreting emblem glyphs main signs as polity names. ${ }^{5}$

\footnotetext{
${ }^{5}$ Alexander Tokovinine (2006) arrived to similar interpretations about the various toponyms in the inscriptions of Naranjo. According to him people from Naranjo identified themselves (and others) as from a wider region named Huk Tzuk, but the site itself was called Maxam. The emblem glyph main sign (Sa'al) distinguished the rulers and gods of Naranjo from other Huk Tzuk sites and was
} 


\section{Pomona}

This is another site less known archaeologically than its neighbours; however its inscriptions are very informative about the toponymic function of emblem glyphs. It is obvious that two emblem glyphs are used in Pomona; both are recorded in toponymic expressions in Pomona and outside of it. All inscriptions of the site come from the Late Classic Period, and form roughly two sets of monuments, one dedicated in 692 (9.13.0.0.0) and the other in 9.18.0.0.0 (790). Middle-seventh century information about Pomona also derives from Palenque inscriptions, but all other mentions of the site appear in monuments of the Late Classic Period.

The emblem glyphs in question are K'UH-pa-ka-b'u-la-AJAW and K'UH-pi-pi-aAJAW (the second was deciphered in David Stuart and Stephen Houston, 1994: 46, 49; figure 13). Both of them are toponyms; this can be confirmed through their etymology and use in inscriptions. The pa-ka-b'u-la sequence can be transcribed as pakb'ul and translated as 'Place where the (Wooden) Lintels Abound' or 'Place where the Sugarcane Abounds' (Lacadena and Wichmann, n.d.: 25-26). It occurs twice as a toponym, once in the inscriptions of Pomona (Panel of the 96 Glyphs K6-L8, reconstructed by Peter Mathews, 2007: 64) and once (?) in Piedras Negras (Stela 12 D8).

In the first case it appears in a clause that ends a retrospective narrative with the dedication of the panel itself (figure 14):

yu-xu-lu-ji K'AN-na-TUN-ni u-pu-wa u-?-wo-jo UH-ti-ya CHAK-ICH'AK-KAB'-EK'pa-ka-b'u-la
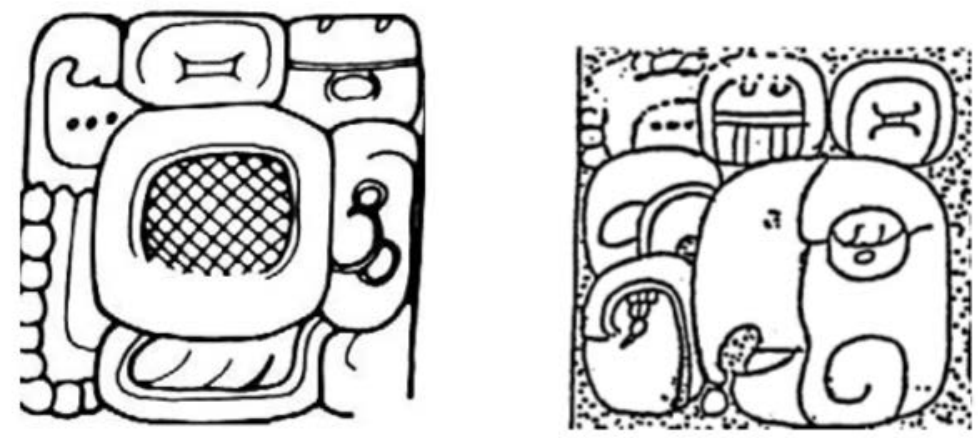

FIGURE 13. pa-ka-b'u-la and pi-pi-a as emblem glyph main signs. Drawings by Peter Mathews and Ian Graham (Stuart, 2007b: 63 and Grube, Martin and Zender, 2002: II-58)

originally the name of a temple in the site. The kings of Naranjo additionally identified themselves with the mythological place Wak Kab' Nal. 
yuxullilj k'a[h]n tun upuw u-? woj uhtiy chak i[h]ch'ak kab' ek' pakb'ul

"he has carved the bench, he ?-ed the ? glyph, it happened at Chak Ihch'ak Kab' Ek' Pakb'ul”

Here, Pakb'ul is behaving like other toponyms and it is preceded by another place name which is also recorded on another Pomona panel now in the Dallas Museum of Fine Arts (Mathews, 2007: 67). In that text it follows the antipassive ha-i K'AL-li-wi ka-b'a sequence which can be transcribed and translated as ha'i kaliw kab' "it was she who tied the earth" followed by the toponym Chak Ihch'ak Kab' Ek' or Red/Great Jaguar Paw Earth Star (figure 15). As both inscriptions came from the main plaza of Pomona it is not impossible that this was the name of this area within the site.

It was Stephen Houston who first brought the example from Piedras Negras Stela 12 to the attention of epigraphers in another context (see Houston et al., 2000b: 101). It is a retrospective mention narrating events in the middle of the $6^{\text {th }}$ century and a visit to Pomona written as T'AB'-yi-ya pa-ka-b'u-la or t'ab' $[a] y[i]$ y pakb'ul "got gone to Pakb'ul" (figure 16).

The other emblem glyph is used as a toponym in Pomona as on Panels 1 and 3 where it follows the root intransitive verb uhti in winikhab' ceremonies indicating that the ritual happened in Pipa' or Pip Ha' (figure 17). The etymology of this place name is difficult to unravel as the only possible word in Maya languages is Yukatek pip meaning 'fat or a kind of bird' (Barrera Vázquez, 1980). However, it could have been easily the name of the Usumacinta River, or a part of it flowing close to Pomona. There is a diachronic distribution of the two emblem glyph main signs. Pipa'/Ha' is restricted to dated contexts before the $7^{\text {th }}$ century (but one in

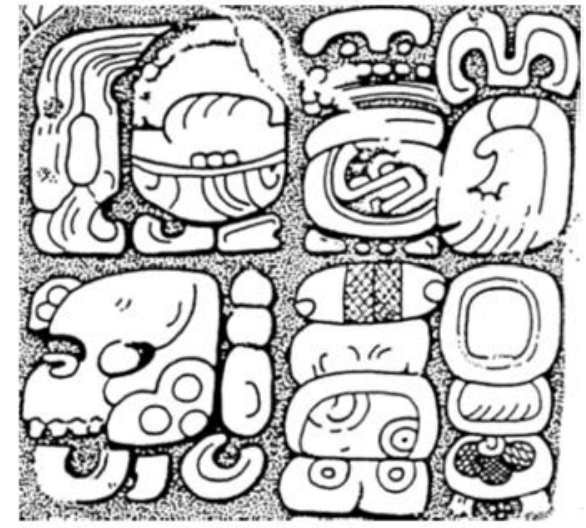

Figure 14. Pomona Panel of the 96 Glyphs. Drawing by Peter Mathews (Stuart, 2007b: 64)

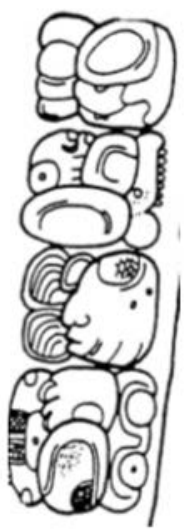

Figure 15. Pomona Door Jamb 3. Drawing by Christian Prager (WAYEB Drawing Archive) 


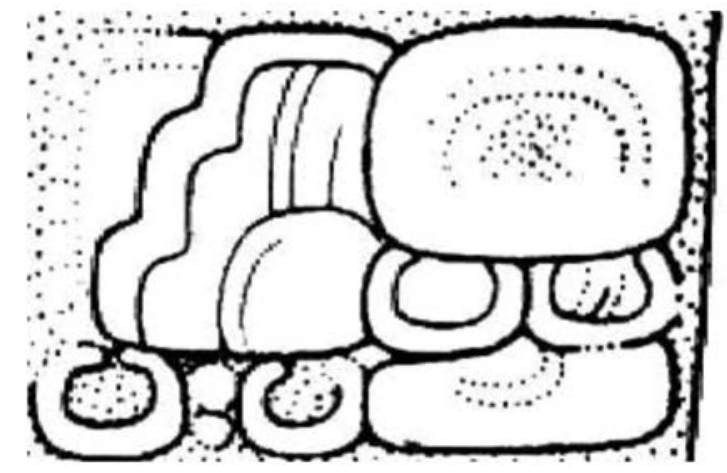

FIGURE 16. TAB'-yi-ya pa-ka-b'u.

Piedras Negras Stela 12, drawing by David Stuart (смнI, 9: 62)

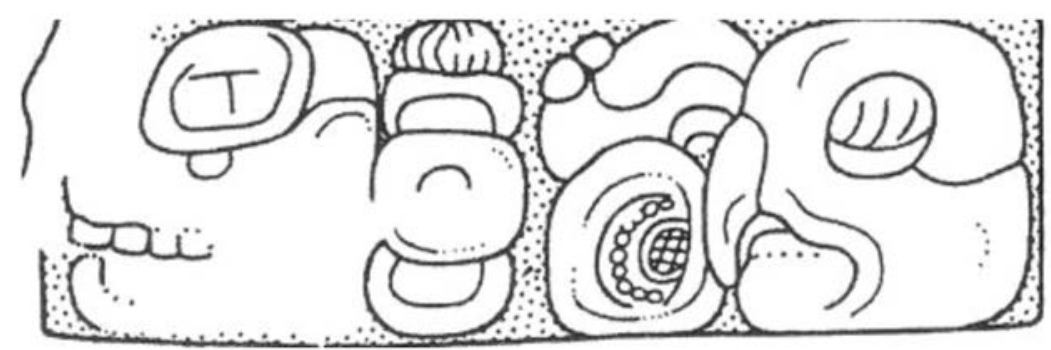

FiguRe 17. UH-ti-ya pi-pi-a.

Pomona Hieroglyphic Panel 1, drawing by Peter Mathews (Stuart, 2007b: 60)
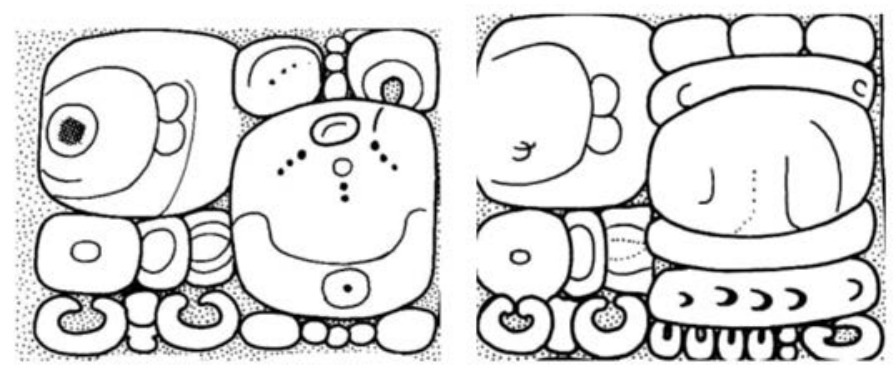

FIGURE 18. TI'-tzi-la and tz'a-le-ji-ya.

Pomona Hieroglyphic Panel 7, drawings by Peter Mathews (Stuart, 2007b: 62) 
Panhale Stela 1, a monument dated 830), while Pakb'ul is used after the $7^{\text {th }}$ century, save the earliest mention of it in the $1^{\text {st }}$ century $\mathrm{AD}$ (retrospectively).

There are at least two other toponyms in the inscriptions of Pomona on Panel 8 connected to the 9.8.0.0.0 and 9.9.0.0.0 period-ending ceremonies. The first one is spelled Tl'-tzi-la while the second is tz'a-le, probably naming either site areas or different sites (figure 18). A similar pattern of winikhab' celebration and various toponyms is attested on Tikal Stela 31 and Dos Pilas Stela 15.

Although hypothetical, the evidence shows that in Pomona, similarly to Palenque, the entire site's name was formed by the -ul toponymic suffix in connection to a river area which was called Pipa'/Ha'. It is not inconceivable that the ruling royal family of the $7^{\text {th }}$ century claimed descent from two separate lines of ancestors. One is connected to Pakb'ul and the other is to Pipa'/Ha', a correlation which can be made in the cases of Yaxchilan and Bonampak.

\section{Piedras Negras}

There are at least two emblem glyphs used by the rulers of the site and both occur in toponymic formulas (Stuart and Houston, 1994: 31-33; Zender, 2002: 170-176; Stuart, 2003). The emblem glyphs are K'UH-yo-ki-b'i-AJAW and K'INni-AJAW (figure 19) while the toponym in question is T5-TUN-ni (figure 20). The more frequent emblem glyph is yokib' a derived noun perhaps meaning 'canyon, entrance' (Stuart and Houston, 1994: 31). On contemporary monuments it is the only emblem glyph main sign without the k'uhul adjective as in Piedras Negras Stela 29 or on the early lintels of Yaxchilan. Its first occurrence with the k'uhul adjective is found on Piedras Negras Stela 34 dated 652.

Its occurrence in toponymic formula is restricted to the text of Piedras Negras Altar 1 (figure 21). The first one (H2-12) is a mythological event as the date indicates (9.0.0.0.0 before the 13.0.0.0.0 of the Creation), however the text maintains that $u / h]$ tiy yokib' chan ch'e'n - "it already happened at Yokib' sky-cave" (see drawing in Stuart and Houston, 1994: 34). The next occurrence is probably connected to a burial ritual where one Piedras Negras ruler, Yo'nal Ahkul, dies
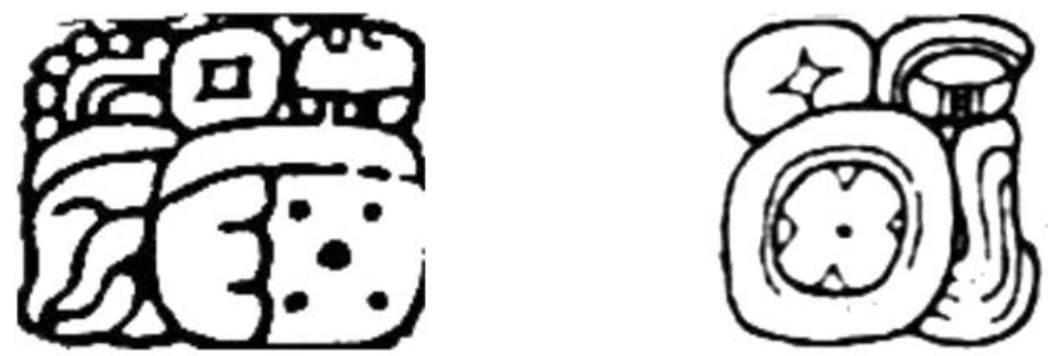

FIGURE 19. yo-ki-b'i and K'IN-ni as emblem glyph main signs.

Drawing by David Stuart (Stuart, 1985: 177) 


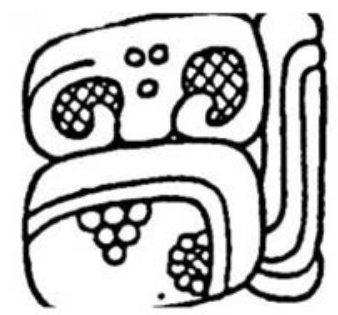

FIGURE 20. T5-TUN-ni.

Drawing by David Stuart (2003: 1)

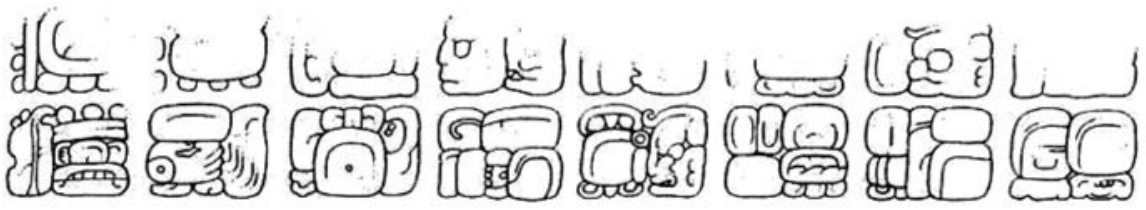

FIGURE 21. Yokib' as toponym, Piedras Negras Altar 1 Fragment B Right Half. Drawing by Stephen Houston (Houston et al., 2003: 225)

(ochb'ihaj) and its funeral ceremony is looked over by a certain Uh? B'ahlam with (yitaj) other dignitaries. The date of the death is connected to the 8.13.0.0.0 (297) period ending ceremony and the text ascertains that it happened in Yokib' (u/h/tiy yokib' chan ch'e'n; see Stuart and Houston, 1994: 34; Houston et al., 2003: 225). Thus, both contemporary and later monuments indicate that Yokib' was an emblem glyph main sign and a toponym.

After the almost fifty-year gap in the inscriptional record of Piedras Negras, Stela 25 was dedicated in 608, at the beginning of the Late Classic Period. The ruler's royal name K'ihnich Yo'nal Ahkul is not new according to retrospective texts; however, he used only the K'IN-ni-AJAW emblem glyph without the k'uhul adjective. From that moment on, all rulers of the site used both emblem glyphs, although K'IN-ni-AJAW was rarely combined with k'uhul. Also, this is the time period when K'IN-ni-a or K'IN-NAL construction shows up in the inscriptions of other sites (Grube, Martin and Zender, 2002: II-25). The last one identifies a captive on Palenque Hieroglyphic Stairway 1 as aj $k^{\prime} i / h / n$ nal, but most mentions come from the $8^{\text {th }}$ century as K'IN-ni-a and AJ-K'IN-ni-a. There is an indirect connection between this toponym and the rulers of Piedras Negras. Namely one of the captured sajal in Palenque was a subordinate of K'ihnich Yo'nal Ahkul II (Zender, 2002: 175).

A third toponym is frequent in the inscriptions of Piedras Negras and El Cayo (Stuart, 2003; Stuart, 2007a). It consists of the undeciphered T5 (Jaguar Paw) logogram and it ends in TUN-ni/tun 'stone', a perfect reference to Altar 4 of Piedras Negras as was first shown by Stuart (2003). The mentions of T5 Tun are very late: they occur on Piedras Negras Throne 1 (785) and El Cayo Panel 1 (775), 
and contrary to David Stuart (2003) I maintain that there is no reason to suggest that T5 Tun was founded in the Early Classic Period. ${ }^{6}$

Indeed, the position of Altar 4, probably in front of Structure 0-12, in the intersection of a line drawn between Structures 0-13 and 0-7 (Satterthwaite, Butler and Mason, 2005: 23) makes it plausible that T5 Tun was the name of the most recently built centre of Piedras Negras, the East Court area. This particular toponym is connected to the last three rulers of Piedras Negras whose monuments are all standing on/in front of buildings surrounding the East Court.

Interestingly, the use and frequency of the three toponyms mirror the pattern of monument dedication and site construction in Piedras Negras. The earliest inscriptions, both within the site and outside it, even retrospective ones, refer to Yokib' which could have been the area around the Southern Court Plaza, the oldest construction group in Piedras Negras (Houston et al., 1998a and b, 1999, 2000a and b, 2001, 2003). It is from here where the royal family originated itself, although latter on it rebuilt the Western Court Area and the royal palace certainly remained there during the whole Late Classic Period. K'ihn Ha', as Marc Zender (2002: 175) suggested, could have referred to the hot sweat baths in Piedras Negras, while T5 Tun was most probably the name of the latest built East Court.

An alternative proposal is that the K'IN-AJAW emblem glyph and the K'ihn Ha' toponym referred to another dynasty residing in a different site. An inscription from Chancala may indicate this solution to be correct (figure 22):

\section{K'AN-na u-? ?-ta AJ-AJAW-K'IN}

k'an $u$ ? ?-Vt k'i/h/n ajaw

This short inscription names an individual who wears the undeciphered headband bird title with the $k^{\prime} i / h / n$ ajaw title. If this is a local mention, then it is possible that Chancala was the original K'ihn Ha' and this would explain both the archaeological frontier discovered in the Chancala Valley (Liendo Estuardo, 2007) and the frequent capture of individuals from K'ihn Ha' recorded in Palenque's inscriptions. As a conclusion, the two emblem glyphs of Piedras Negras were used as toponyms and they could have referred to different areas of the site itself, or indeed two separate sites.

\section{Yaxchilan}

A site which has also two emblem glyphs, one recently deciphered by Erik Boot (2004) and Simon Martin (2004a) as K'UH-PA'CHAN-AJAW, while the other is still

\footnotetext{
${ }^{6}$ In the text of Stela 25:D1 it is recorded that the accession of K'ihnich Yo'nakl Ahkul occured in a site called mu-k'i-TUN-ni. Although direct evidence is lacking, this can be the phonetic spelling of T5 Tun. However muk' means "grande/big” in Tzeltalan languages (Haviland, 1981) which seemingly does not fit the iconographic form of T5.
} 
undeciphered: K'UH-?-ji-AJAW (figure 23). Several authors dealt with the chronological and spatial distribution of the Yaxchilan emblem glyphs (Mathews, 1988 [1997]: 68; Schüren, 1992). Mathews concluded that the distribution of the emblem glyph main signs shows only two patterns: Pa'chan is the only one mentioned in other sites, while ?-ji is connected to women.

Schüren (1992) went further in his investigation and proposed the existence of two separate sites, Pa'chan and ?-ji, and also suggested that at least two women, Ix Pakal and Ix Chak Chami from ?-ji married into the royal family of Pa'chan. This resulted in the joining of the two polities during the reign of Itzamnaj B'ahlam III who in his inscriptions projected this political situation into the past. Finally, he noted the unlocated Laxtunich as the possible ?-ji (Schüren, 1992: 37).

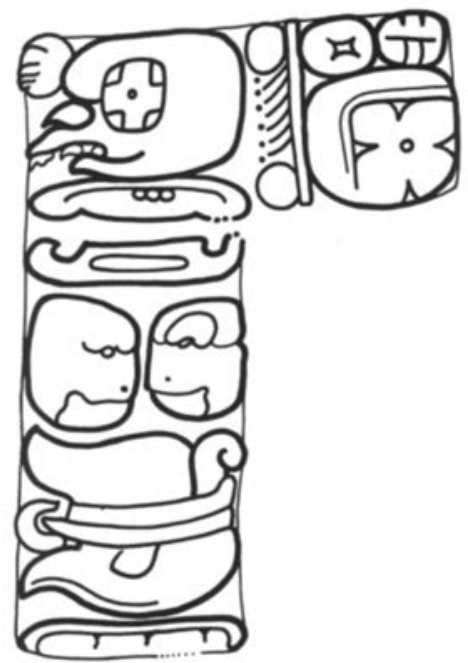

Figure 22. Panel from Chancala.

Drawing by Christian Prager (WAYEB Drawing Archive)
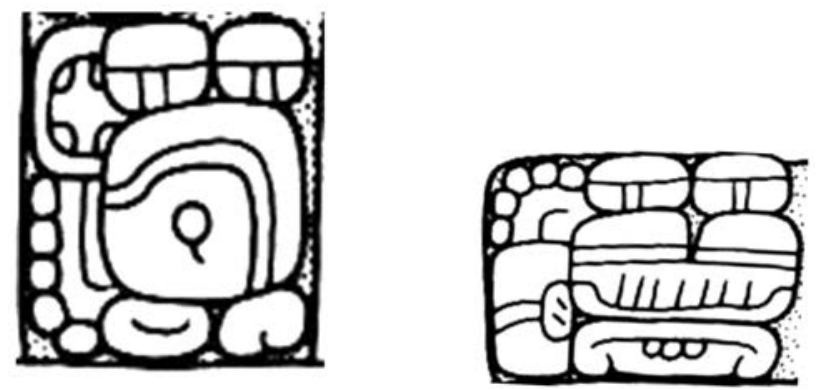

FigURE 23. K'UH-?-AJAW and K'UH-PA'CHAN-na-AJAW.

Drawings by Ian Graham (CMHI, 3: 15) 
As an alternative to these interpretations, there is enough evidence now to suggest that both emblem glyphs were used simultaneously in El Zotz in the $5^{\text {th }}$ century pointing to the possibility of an origin of the Yaxchilan dynasty. ${ }^{7}$ Also, David Stuart (2007b: 31) has recently shown that there were two dynastic counts in Yaxchilan (as recorded on Dos Caobas Stela 1): one counting 15 rulers from Yopat B'ahlam who was a k'uhul pa'chan ajaw and another counting more than 20 rulers from a k'uhul ?-[jil-ajaw. Interestingly, the two numbers are different (thus, they may involve sometimes different persons) and it is possible that Itzamnaj B'ahlam III (to whom the count refers) was indeed the first with whom the counts joined.

Nevertheless, the El Zotz origin makes it likely that neither Pa'chan nor ?-ji were place names referring to Yaxchilan or another site in the region but to locales in Peten. For the Late Classic Period Pa'chan could have become the local toponym in Yaxchilan, since it is mentioned twice as such on Lintel 25 (ta/h/n ha' pa'chan and yo[h/l ta[h]nal ta[h]n ha' pa'chan] and referred as the kab'-ch'e'n of Itzamnaj B'ahlam III (figure 24).

There are indications that Yaxchilan had its own internal parts with different toponyms. As David Stuart pointed out there is a third emblem glyph connected to one ruler (Itzamnaj B'ahlam II) of the site which can be read as k'uhul muwan ajaw and is mentioned on an unprovenanced hieroglyphic stairway block possibly coming from El Chorro (Stuart, 2007b: 39; figure 25). On Yaxchilan Stela 4 (figure

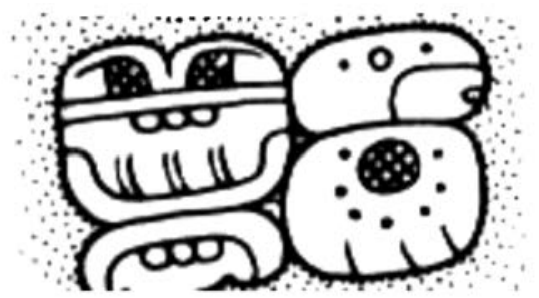

FIGURE 24. TAN-HA'-PA'CHAN-na.

Yaxchilan Lintel 25, drawing by Ian Graham (смнг, 3: 55)

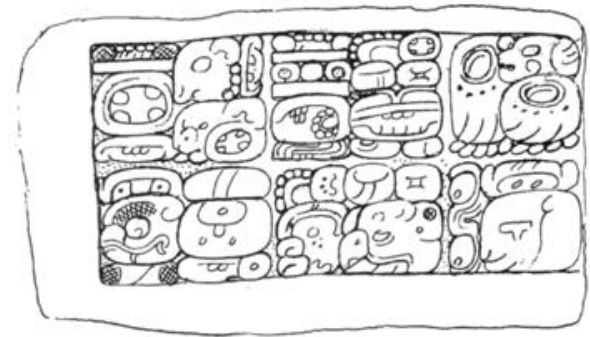

Figure 25. El Chorro Hieroglyphic Stairway Step. Drawing by David Stuart (Stuart, 2007b: 34)

${ }^{7}$ This idea was suggested by David Stuart (in Houston, 2000: 173; Houston et al., 2003: 236; email by David Stuart, 4 August, 2005). 
26) a Muwan bird is topped with a Pa'chan glyph probably indicating a specific place within Yaxchilan (Stuart, 2007b: 4). A similar iconographic representation occurs on the back of Stela 7 and on Step III of Hieroglyphic Stairway 3 where a place name probably read Ahin Ha' was carved on the base of the monuments indicating the place where the events happened (figure 27 and 28).

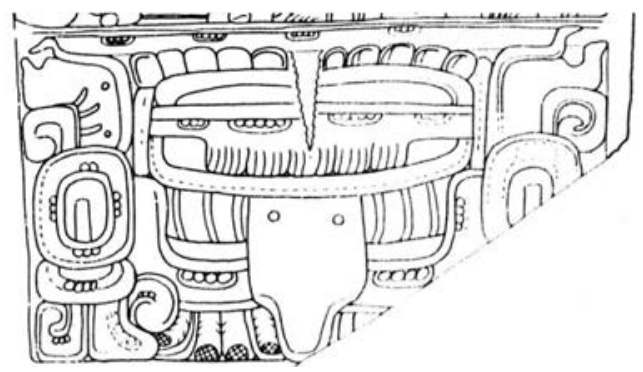

Figure 26. Yaxchilan Stela 4.

Drawing by Carolyne Tate (Tate, 1992: 67)

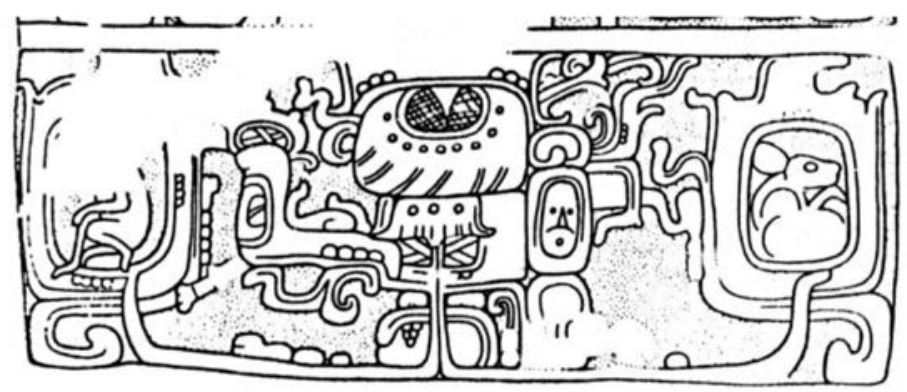

FIGURE 27. Yaxchilan Stela 7.

Drawing by Ian Graham (Tate, 1992: 89)

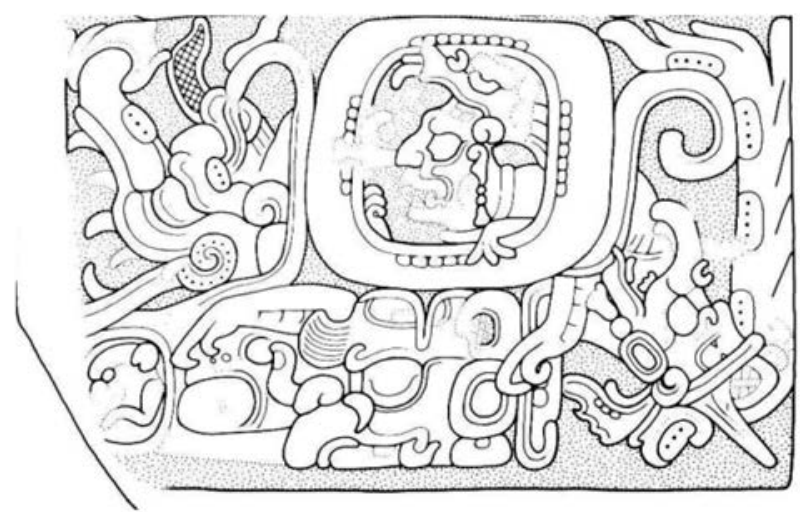

FIGURE 28. Yaxchilan Hieroglyphic Stairway III, Step 3 Drawing by Ian Graham (CMHI, 3: 169) 
Other indications of intersite toponyms can be extracted from royal titles which are seldom interpreted as containing place names. Yaxun B'ahlam III, Itzamnaj B'ahlam III, Yaxun B'ahlam IV and Itzamnaj B'ahlam IV all have their specific title occurring only with them and only in Yaxchilan. Yaxun B'ahlam III has $a j$ wak tun, Itzamnaj B'ahlam III has aj k'an patam te' and Yaxun B'ahlam IV has aj yax chopat. They are difficult to translate, however it is not inconceivable that they referred to specific parts of the site connected to each ruler.

In Yaxchilan, a complex pattern emerges concerning the use of emblem glyph main signs. Originally the Yaxchilan emblem glyphs named places in the region of El Zotz, but later on a migrating royal branch brought them to Yaxchilan. Also, there is a small hint that they referred to two different royal families and Pa'chan was more important for the rulers of Yaxchilan. There are candidates for local place names in the inscriptions of Yaxchilan designating various areas of the site, or the site itself. However, during the Late Classic Period Pa'chan became the more encompassing toponym among several others.

\section{Ak'e-Xukalnah}

Both emblem glyphs were connected to known sites, Bonampak and Lakanha, by epigraphers in the past (Mathews, 1980). However, recent investigation rather shows that the situation was much more complex than simple one-to-one correspondence (Sachse, 1996; Beliaev and Safronov, 2004). Indeed, Sachse (1996) drew attention to the fact that, originally, Bonampak had the Xukalnah emblem glyph, while Beliaev and Safronov (2004) accepted that Xukalnah originally was the emblem glyph of Lakanha, while Ak'e named an unknown site in the region.

The Ak'e emblem glyph is always written with two syllabograms a-k'e (figure 29) and it combines with the ajaw and k'uhul adjective (this occurs the first time on the redated Sculptured Stone 2 in 605; Bíró, 2007). The spelling of Xukalnaah is more varied. However, in most cases it is written with the syllabograms xu-kala and the logogram NAH for 'house' (figure 30). It also stands with k'uhul, ajaw

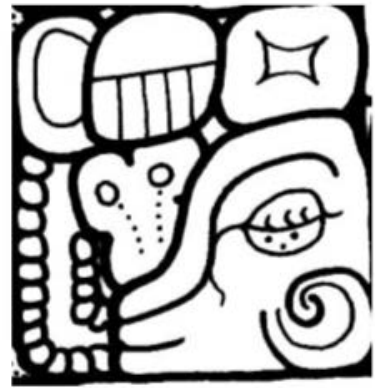

Figure 29. K'UH-a-k'e AJAW. Drawing by Alexandr Safronov (WAYEB Drawing Archive)

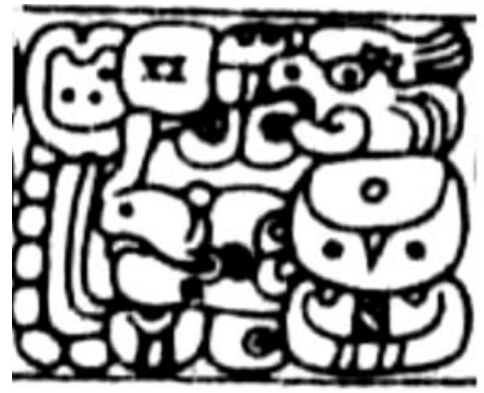

FIGURE 30. K'UH-xu-ka-la-NAH-AJAW-wa. Drawing by Peter Mathews (Mathews, 1980: 63) 
and also with the agentive prefix aj. Neither emblem glyph main sign appears in toponymic formula nor is it used with the chan-ch'e'n difrasismo.

The rulers of Bonampak used the Xukalnah emblem glyph as their own during the Late Classic Period meanwhile the name of the site or a part of it was Usiij Witznal as was deciphered recently by David Stuart (2007a). Unfortunately, in the inscriptions of Lakanha, Xukalnah is the only emblem glyph and it refers to a sajal whose son later became the ruler of Bonampak.

There are various other place names in the Selva Lacandona area whose rulers used the xukalnah ajaw title: b'ub'ul ha' (probably Ojo de Agua), saklakal, (payal) jukub', Knot-Site and $t a$ ' mentioned in several inscriptions (Beliaev and Safronov, 2004). This complex political situation is very similar to that of Tikal and Dos Pilas, or to that of Palenque, Tortuguero and Comalcalco. The only pair where epigraphers had a detailed story about the use of the same emblem glyph in different places indicates that one royal family was split in two and one branch migrated to a new place where it continued to use the original emblem glyph.

I think the most plausible and simple interpretation is to suggest the existence of two royal dynasties, Xukalnah and Ak'e that had their seats in different sites. Originally Xukalnah might have been Lakanha, the site with the greatest construction area and very early monuments. During the Late Classic Period various members of this dynasty claimed the xukalnah ajaw emblem glyph, among them the rulers of Bonampak and Ojo de Agua. It is therefore not exactly clear which xukaInah ajaw is mentioned in the inscriptions of Yaxchilan for additional information is omitted. Also, there are indications that the branches of the Xukalnah dynasty had less than friendly relations among each other as indicated by the ongoing conflicts of the lords of Usij Witznal with the rulers of the Knot-Site.

\section{Other emblem glyphs}

There are other full emblem glyphs in the region, though they appeared with the $k^{\prime} u h u l$ adjective only after the $8^{\text {th }}$ century. This can be a documentation problem because a substantial amount of monuments is unprovenanced or the sites are not even surveyed yet. The most important dynasties were the lords of lakamtun (El Palma), saktz'i', wak'a-? (Santa Elena), ama-?-la (Moral), naman (La Florida), chan (Chinkultic), chak k'uh? (Chinikiha), peptun (La Mar), pomoy and b'u/h/ktun. ${ }^{8}$ Interestingly, one of the most frequently mentioned emblem glyphs in the region, sak $t z$ 'i' never appears with the k'uhul adjective, maybe due to the lack of more monuments from the site itself.

La Florida, El Palma and Chinkultic all had their full emblem glyphs, while Chinikiha and La Mar never had the k'uhul adjective, though their lords were ajaw. In the case of La Mar there is good evidence to suggest that it was a subordinate

\footnotetext{
${ }^{8}$ Various authors suggested these names and identifications, a good summary of them in the works of Marc Zender (2002) and David Stuart (2007a).
} 
site during the Late Classic Period to various other polities such as Palenque and Piedras Negras, while Chinikiha's importance is absolutely unknown and it is not impossible that it was a subordinate of Pomona or Palenque. Lakamtun, Wak'a-?, Ama-?-la, Peptun and Pomoy all stand with the aj agentive prefix though neither of them occurs with any of the toponymic markers in the inscriptions.

\section{Discussion}

The distinction between emblem glyphs prefixed by the adjective k'uhul and not prefixed by it is much more nuanced in the Western Maya Region than elsewhere. The Southern Campeche region has only two full emblem glyphs, k'uhul kanul ajaw and k'uhul BAT ajaw, the first one maybe pertaining to an intrusive dynasty to the region, while the second one maybe referring to the most important dynasty before and after the apogee of the Snake lords (Martin, 2005; Grube, 2005). Interestingly, all other toponymic titles are in connection with ajaw, nevertheless there are indications that other well-known titles existed in the region such as $a j$ k'uhu'n, ti' sak hun, a'nab' and sajal.

During the Late Classic Period and beyond, there is no indication that lords with toponymic titles formerly without k'uhul ever acquired the right to use this adjective. The Peten region shows a similar pattern: various ancient dynasties with full emblem glyphs from the $5^{\text {th }}$ century on and a complex array of sites all using toponymic titles. Nevertheless, most of the emblem glyph main signs refer to the sites themselves such as Tikal (Mutul or Yax Mutul), Yaxha (Yaxha'), Ucanal (Kan Witznal), Naranjo (Sa'al), Pusilha (Un?), Altun Ha' (?), Motul de San Jose (Ik'a or Ik' Ha'), Zapote Bobal (Hix Witz), El Peru (Waka' or Wak Ha'), Ixtutz (Kab'al?), Ixkun (Julpi), Sacul (Jul), Xunantunich (Kat Witz), Nakum (?) and Yotz. Also, there are various sites where there is no k'uhul in the titles of ajaw, such as Xultun, Topoxte, Rio Azul, Bital, Kokom etc. Only in certain cases there is evidence that the local toponym was different from the one in the emblem glyph main sign, like the case of Caracol whose name was Ux Witz Ha' whereas its emblem glyph was k'uhul k'antu' mak.

Although the literature talks about a post-800 'balkanization', it is only in the case of Tikal that there is evidence about the splitting of the dynasty and the use of its emblem glyph in various other sites such as Jimbal and Ixlu in the $9^{\text {th }}$ century. The situation in the Petexbatun Region is very similar to that of the Peten, namely there are various dynasties whose emblem glyph main sign is similar to their toponyms such as Seibal, Tamarindito and Altar de Sacrificios. In the case of Machaquila, Tres Islas and Cancuen it is not possible to establish any difference between the emblem glyph main sign and the local toponym. The rulers of Dos Pilas and later Aguateca claimed their origins from Tikal, although they settled down in separate cities which were not much inhabited before their arrival. In the same region, it is conspicuous the lack of inscriptions commissioned by second- 
ary nobles; however, Dos Pilas and Cancuen rulers represented them on very late monuments.

The Southeast Region is a bit understudied in respect of toponyms, but it is known that Copan's emblem glyph was a chan-ch'e'n and Copan rulers may took their origin from Ux Witz Ha' or Caracol as has recently been suggested by David Stuart (2007c). Only three place names stand in the inscriptions of Copan with the chan/kab'-ch'e'n difrasismo: the emblem glyph main sign, ux witik and yutuk (Schele and Looper, 2004: 358; Bíró, 2010). Sometimes the Ux Witik place name appears without numbers as witik or k'uhul witik (Schele and Looper, 2004: 359). Also there is evidence that the place name was wintik (Copan Stela 10).

From the earliest inscriptions, both witik and the emblem glyph main sign name stand in toponymic formula, sometimes in the same texts. However, Ux Witik never stands as the main sign of a full emblem glyph. It is therefore more probable that the Copan main sign emblem glyph referred to a place where the royal dynasty originated. This hypothesis is in contradiction with the origin of Yax K'uk' Mo' from Ux Witz Ha' or Caracol (Stuart, 2007c). Indeed, it is equally possible that ?-pi referred to a minor area of Caracol, one part of this larger site, and therefore it became important to indicate Ux Witik as the locale of the new dynasty.

I believe that in the majority of the cases the emblem glyph main signs were place names. They are formed in different ways such as using the suffixes -il, $-u l$ and -al (Pakb'ul, Mutul, Kanul, Mahsul, B'ak(V)l, Sa'al); ${ }^{9}$ describing natural phenomena like $h a$ ' 'water' (Pip Ha', Kihn Ha', Popo' Ha', Wak Ha', Yax Ha', Ik' Ha' and Itz Ha', though see the arguments of Boot 2005 above), and witz 'hill, mountain' (K'an Witznal, Kat Witz, Hix Witz, Witz Nal) and tun 'stone' (Lakamtun) and chan $\sim$ sky (Pa'chan). Other elements are much rarer such as nah 'house' like in Xukalnah.

Toponymic titles contain frequently the same elements such as Ux Witz Ha', B'ub'ul Ha', Lakam Ha', Chak Ha', K'ihnal Ha', 'Dragon'-Ha', 'Alligator'-Ha', Yax Nil, B'uhktun, Peptun, Ux Te' Tun, K'ihnich Pa' Witz, and still other geographical phenomena like Chik Nahb' etc. There is no difference between mythological, site area and main sign emblem glyph place names as is shown by the examples of Matwil, Ho' Janab' Witz, Mo' Witz, Tukun Witz, Wak Kab' Nal, Wak Chan Nal, Wak Hix Nal, Wak Chan Muyal Nal/Witz or Nah Ho' Chan.

From this rather short list and comparison, my conclusion is that emblem glyph main signs were toponyms and they were referring to very specific places such as mountains, rivers or just one part of a river, or buildings and other natural phenomena. They were the same as other toponymic titles and evidence proves that originally there was no difference among full emblem glyphs and toponymic titles. The rulers of Tikal, Calakmul, Piedras Negras, Yaxchilan, Tonina,

\footnotetext{
${ }^{9}$ Alexander Tokovinine (2007b), Erik Boot (2009) and Carlos Pallán (2009: 120-122) gave a full list of derivational suffixes for toponyms attested in Classic Period inscriptions.
} 
Xukalnah, Ak'e, Naranjo, Copan etc. all used their emblem glyph main signs as toponyms and without the k'uhul adjective in the Early Classic Period. In Tikal, Naranjo and Piedras Negras, it is probable that the emblem glyph main signs referred to a part of the site. Specifically in Naranjo and Piedras Negras those main signs from the earliest periods indicated concrete sites of royal ceremonies.

\section{Conclusion}

Conceptually, all of the toponyms were chan-ch'e'n and the only difference is more chronological than real, namely from the $5^{\text {th }}-6^{\text {th }}$ centuries a substantial part of them stands in toponymic titles with the k'uhul adjective. This chronological change, however, cannot be equated with a geographical differentiation, that is k'uhul $\mathrm{x}$ ajaw=polity name and $\mathrm{x}$ ajaw=site name. There are regional names in the inscriptions such as Ux Te' Tun, Huk Tzuk and Uxlajun Tzuk, Ux Hab' Te' etc. (Beliaev, 1998). Nevertheless, they are rarely forming part of toponymic titles, though they frequently stand with the agentive prefix $a j$-indicating someone's origin from a given region which is most of the time specified (narrowed down) further with an additional toponym.

There is no evidence in the inscriptions that emblem glyphs functioned as polity names. They were specific places, whole sites or site areas, and indicated the origin of a given royal family. In several cases, there was a difference between the emblem glyph main sign and the local toponym which has to be explained: it can be that the local toponym referred to a new royal seat (as in the cases of Lakam Ha', Ux Witik, 'Dragon'-Ha', K'ahk' Witz and Chik Nahb') because of migration, while in other cases it can be that they were indicating new additions and buildings to an existing place (for example Yokib'-K'ihn-Ha'-T5 Tun, or the case of Pip Ha' and Pakb'ul). Still, in another case, the formerly different sites' histories are so intertwined that even in a new place the old toponym is transposed (probably this happened in the case of Yaxchilan where there are two dynastic counts and three emblem glyphs). ${ }^{10}$ But as a general rule when the emblem glyph main sign and the local toponym are different this can potentially indicate that a given royal house is intrusive to the site.

Therefore I propose that emblem glyph main signs are toponyms. They labeled royal houses and their connection to the ancestral origin place was very strong as they remained constant even if the family moved to another place. Through them, pieces of a Classic Period elite conception of territory are expressed in

\footnotetext{
10 "It may be our notion of the Maya "polity" that is at fault. We need a definition that sits comfortably with dramatic-if rare-shifts in location, and the transfer of identity and affiliation that affects not only places but whole populations. In essence, these emblem names seem to label royal houses whose connections to specific territories are less intrinsic than habitual." Martin (2005: 12).
} 
connection not only to an actual landscape but to places of origin intertwined with codes of legitimacy. ${ }^{11}$

\section{REFERENCES}

Ayala, Maricela

1995 "The History of Tonina through its Inscriptions", tesis de doctorado. Austin: University of Texas, Departament of Art History.

Barnhart, Edwin L.

1999 "The Palenque Mapping Project, 1999 Field Season Report”, Foundation for the Advancement of Mesoamerican Studies (FAMSI) < http://www.famsi.org/ reports/98063/index.html >. [Retrieved April 13, 2011.]

2007 "Indicators of Urbanism at Palenque", Palenque: Recent Investigation at the Classic Maya Centre. Damien B. Marken (ed.). Lanham [United States]: Altamira Press, 107-121.

Barrera Vásquez, Alfredo (ed.)

1980 Diccionario Maya Cordemex, Maya Español, Español-Maya. Mérida: Ediciones Cordemex.

Barthel, Thomas S.

1968 "Historisches in dem Klassischen Mayainschriften", Zeitschfrift für Ethnologie, 93: 119-156. Braunschweig [Alemania].

Beliaev, Dmitri D.

1998 "Wuk Tsuk and Oxlahun Tsuk: Tikal and Naranjo in the Late Classic". Manuscript.

Beliaev, Dmitri D. and Alexander Safronov

2004 "Ak'e y Xukalnaah: istoriya y politicheskaya geografia gosudarstv maya Verhney Usumacinti”, Mesoamerica < http:/www.mesoamerica.ru/indians/maya/ ake.html>. [Retrieved April 13, 2011.]

Berlin, Heinrich

1958 "El glifo emblema en las inscripciones mayas", Journal de la Société des Américanistes, 47: 111-119. Paris: Société des Américanistes.

${ }^{11}$ Here I evoke a well-known example from the history of Europe, namely the case of the Habsburgs. While they originated from today's Switzerland, and named after a castle there, later they ruled in Austria, Spain and Hungary. These new territories were never renamed as Habsburg, though the dynasty rarely called itself otherwise. Eventually, the Habsburgs lost their possessions in Switzerland, but not their name. Also, the house split into more than one branch which kept using the Habsburg name in different territories. 
Bernal Romero, Guillermo and Benito Jesús Venegas Durán

2005 "Las familias de Palenque: poder dinástico y tejido social del señorío de B’akaal, durante el periodo Clásico Tárdio”, Lakamha', 16: 9-13. Mexico: Museo de Palenque.

Bíró, Péter

2007 "Las piedras labradas 2, 4 y 5 de Bonampak y los reyes de Xukalnaah en el siglo 7", Estudios de Cultura Maya, XXIX: 31-61. Mexico: Universidad Nacional Autónoma de México, Instituto de Investigaciones Filológicas, Centro de Estudios Mayas.

2010 "A New Look at the Inscription of Copan Altar K”, PARI Journal, 11 (2): 22-28. San Francisco: Pre-Columbian Art Research Institute

Boot, Erik

2002

"The Life and Times of B'alah Chan K'awil of Mutal (Dos Pilas) according to Dos Pilas Hieroglyphic Stairway 2", Mesoweb <http://www.mesoweb.com/ features/boot/DPLHS2.pdf $>$. [Retrieved April 13, 2011.]

2004 "T299 Split as the Logographic Sign for PA”, Wayeb Notes No. $13<$ http:// www.wayeb.org/notes/wayeb_notes0013.pdf>. [Retrieved April 13, 2011.]

2005 Continuity and Change in Text and Image at Chichen Itza, Yucatan, Mexico: A Study of the Inscriptions, Iconography, and Architecture at a Late Classic to Early Postclassic Maya Site. Leiden [Netherlands]: cnws Publications.

2009 "The Updated Preliminary Classic Maya-English, English-Classic Maya Vocabulary of Hieroglyphic Readings, April 2009", Mesoweb Resources < http:// www.mesoweb.com/resources/vocabulary/Vocabulary-2009.01.pdf $>$. [Retrieved April 13, 2011.]

Corpus of Maya Hieroglyphic Inscriptions. Volumes 1-9 (смні)

1977- Cambridge: Harvard University, Peabody Museum of Archaeology and Ethnology.

Foundation for the Advancement of Mesoamerican Studies (FAMSI)

Linda Schele Drawing Collection <http://www.famsi.org/research/schele/index. html >. [Retrieved April 13, 2011.]

Grube, Nikolai

2005 "Toponyms, Emblem Glyphs, and the Political Geography of Southern Campeche", Anthropological Notebooks of the Slovene Anthropological Society 11: 87-100. Ljubljana [Slovenia]: Slovene Anthropological Society.

Grube, Nikolai, Simon Martin and Marc Zender

2002 Palenque and Its Neighbors, Notebook for the XXVIth Maya Hieroglyphic Forum at Texas, 2002. Austin: University of Texas, Department of Art History.

Guenter, Stanley P.

2003 “The Inscriptions of Dos Pilas Associated with B'ajlaj Chan K'awiil”, Mesoweb <http://www.mesoweb.com/features/guenter/DosPilas.pdf >. [Retrieved April 13, 2011.] 
Haviland, John B.

1981 Sk'op sotz’leb: el tzotzil de San Lorenzo Zinacantán. Mexico: Universidad Nacional Autónoma de México.

Houston, Stephen D.

1986 "Problematic Emblem Glyphs: Examples from Altar de Sacrificios, El Chorro, Rio Azul, and Xultun”, Research Reports on Ancient Maya Writing, 3: 1-11. Ashville [United States]: Centre for Maya Research.

1993 Hieroglyphs and History at Dos Pilas Dynastic Politics of the Classic Maya. Austin: University of Texas at Austin.

2000 "Into the Minds of Ancients: Advances in Maya Glyph Studies", Journal of World Prehistory, 14 (2): 121- 120. New York: Plenum Press.

Houston, Stephen D. and David Stuart

1996 "Of Gods, Glyphs, and Kings: Divinity and Rulership among the Classic Maya”, Antiquity, 70: 289-312. York: University of York.

2001 "Peopling the Classic Maya Court", Royal Courts of the Ancient Maya, vol. 1. Takeshi Inomata and Stephen D. Houston (eds.). Boulder [United States]: Westview Press, 54-83.

Houston et al.

1998a "Monumental Architecture at Piedras Negras: Time, History, Meaning", Mayab, 11: 40-56. Madrid: Sociedad Española de Estudios Mayas.

1998b "On the River of Ruins: Explorations at Piedras Negras, Guatemala 1997", Mexicon, 20 (1): 16-22. Markt Schwaben [Germany]: Verlag von Saurwein.

1999 "Between Mountains and Sea: Investigations at Piedras Negras, Guatemala, 1998”, Mexicon, 21 (1): 8-17. Markt Schwaben [Germany]: Verlag von Saurwein.

2000a "Among the River Kings: Archaeological Research at Piedras Negras, Guatemala, 1999", Mexicon, 22 (1): 8-17. Markt Schwaben [Germany]: Verlag von Saurwein.

2000b "In the Land of the Turtle Lords: Archaeological Investigations at Piedras Negras, Guatemala, 2000”, Mexicon, 22 (5): 97-110. Markt Schwaben [Germany]: Verlag von Saurwein.

2001 "Crónica de una muerte anunciada: los años finales de Piedras Negras", Reconstruyendo la ciudad maya: el urbanismo en las sociedades antiguas, Andrés Ciudad Ruiz, María Iglesia Ponce de León and Ma. del Carmen Martínez Martínez (eds). Madrid: Sociedad Española de Estudios Mayas, 65-93.

2003 "The Moral Community: Maya Settlement Transformation at Piedras Negras, Guatemala”, The Social Construction of Ancient Cities. Monica Smith (ed.). Washington DC: Smithsonian Institution Press, 212-253.

Kelley, David H.

1976 Deciphering the Maya Script. Austin: University of Texas Press.

Lacadena, Alfonso and Søren Wichmann

n.d. "Harmony Rules and the Suffix Domain: A Study of Maya Scribal Conventions". Manuscript. 
Liendo Estuardo, Rodrigo

2007 "The problem of political integration in the Kingdom of Baak", Palenque: Recent Investigations at the Classic Maya Center. Damien R. Marken (ed.), Lanham [United States]: Altamira Press, 85-106.

Marcus, Joyce

1973 "Territorial Organization of the Lowland Classic Maya", Science, 180: 911916. United States: American Association for the Advancement of Science.

Martin, Simon

1996 “Tikal's Star Wars Against Naranjo”, Eighth Palenque Round Table, 1993. Martha J. Macri and Jan McHargue (eds.). San Francisco: Pre-Columbian Art Research Institute. <http://www.mesoweb.com/pari/publications/RT10/StarWar.pdf $>$. [Reterieved April 13, 2011.] 1-4.

2003 "Moral-Reforma y la contienda por el oriente de Tabasco". Arqueología Mexicana, XI (61): 44-47. Mexico: Raíces / Instituto Nacional de Antropología e Historia.

2004 "A Broken Sky: The Ancient Name of Yaxchilan as Pa'Chan”, PARI Journal, 5 (1): 1-7. San Francisco: Pre-Columbian Research Institute.

2004a Courtly Art of Ancient Maya. San Francisco: Thames and Hudson.

2005 "Of Snakes and Bats: Shifting Identities at Calakmul", PARI Journal, 6 (2): 5-13. San Francisco: Pre-Columbian Research Institute.

Martin, Simon and Nikolai Grube

1994 "Evidence for Macro-Political Organization Amongst Classic Maya Lowland States". Manuscript.

$2000 \quad$ Chronicle of Maya King and Queens: Deciphering of the Ancient Dynasties of the Ancient Maya. London: Thames and Hudson.

Mathews, Peter

1980 "Notes on the Dynastic Sequence of Bonampak, Part 1", Third Palenque Round Table, 1978. Merle Green Robertson (ed.). Austin and London: University of Texas Press, 60-73.

1988 La escultura de Yaxchilan. Mexico: Instituto Nacional de Antropología e His[1997] toria.

1991 "Classic Maya Emblem Glyphs”, Classic Maya Political History: Epigraphic

[1996] and Archaeological Evidence. Patrick T. Culbert (ed.). Cambridge: Cambridge University Press, 19-29.

2007 "Selected Inscriptions of Pomona and its Vicinity", Inscriptions of the River Cities: Yaxchilan, Piedras Negras and Pomona, Sourcebook for the XXXI Maya Meetings at Texas. David Stuart (ed). Austin: University of Texas, Department of Art and Art History, Mesoamerica Center, 57-67.

Mathews, Peter and John Justeson

1984 "Patterns of Sign Substitution in Mayan Hieroglyphic Writing: the Affix Cluster", Phoneticism in Mayan Hieroglyphic Writing. John S. Justeson and Lyle Campbell (eds.). Albany: State University of New York (Institute for Mesoamerican Studies Publication, 9), 185-231. 
Pallán, Carlos

2009 "Secuencia dinástica, glifos emblema, y topónimos en las inscripciones jeroglíficas en Edzná, Campeche (600-900): implicaciones históricas”, tesis de maestría en Estudios Mesoamericanos. Mexico: Universidad Nacional Autónoma de México, Facultad de Filosofía y Letras, Instituto de Investigaciones Filológicas.

Proskouriakoff, Tatiana

1960 "Historical Implications of a Pattern of Dates at Piedras Negras, Guatemala", American Antiquity, 25 (4): 454-575. United States: Society for American Archaeology.

Ringle, William

1988 "Of Mice and Monkeys: The Value and Meaning of T1016, the God C Hieroglyph”, Research Report on Ancient Maya Writing, 18: 1-22. Washington DC: Center for Maya Research.

Sachse, Frauke

1996 "A New Identification of the Bonampak Emblem Glyph". Paper presented at the first European Maya Conference: Maya Kings and Warfare at the Usumacinta Basin. London, June 22-26, 1996.

Satterthwaite, Linton. Jr., Mary Butler and J. Alden Mason

2005 Piedras Negras Archaeology, 1931-1939: Piedras Negras Preliminary Papers. Piedras Negras Archaeology: Architecture. John M. Weeks, Jane Hill and Charles Golden (eds.). Philadelphia: University of Pennsylvania Museum of Archaeology and Anthropology.

Schele, Linda and David Freidel

1990 A Forest of Kings: The Untold Story of the Ancient Maya. New York: William Morrow.

Schele, Linda and Nikolai Grube

1994 The Peten Wars, Notebook for the XVIIIth Maya Hieroglyphic Workshop at Texas, 1994. Austin: University of Texas, Department of Art History.

Schele, Linda and Matthew Looper

2004 "Seats of Power at Copan”. In Copan: The History of an Ancient Maya Kingdom. E. Wyllys Andrews and William L. Fash (eds). Santa Fe: School of American Research Press, 345-372.

Schele, Linda and Peter Mathews

1998 The Code of Kings: The Language of Seven Sacred Maya Temples and Tombs. New York: Scribner.

Schüren, Ute

1992 "The Yaxchilan Emblem Glyphs: Indicators of Political Change and Expansion of a Classic Maya Polity”, Mexicon, 14 (2): 30-39. Markt Schwaben [Germany]: Anton von Saurwein. 
Stuart, David

1985 "The Inscriptions on Four Shell Plaques from Piedras Negras", Fourth Palenque Round Table. Merle Greene Robertson and Elizabeth P. Benson (eds.). San Francisco: Pre-Columbian Art Research Institute, 175-183.

1990 “A New Decipherment of "Directional Count" Glyphs", Ancient Mesoamerica, 1 (2): 213-224.

1995 “A Study of Maya Inscriptions”. PhD Thesis. Nashville: Vanderbilt University, Department of Anthropology.

2003 "The Paw Stone: The Place Name of Piedras Negras, Guatemala”. PARI Journal, 4 (3):1-6. San Francisco: Pre-Columbian Art Research Institute.

2005 The Inscriptions at Temple XIX at Palenque: A Commentary. San Francisco: PreColumbian Art Research Institute.

2007a "Place Names and Polities in the Usumacinta Region". Paper presented at the XXXI Annual Maya Meetings at Texas. Austin, March 9-14, 2007.

2007b Inscriptions of the River Cities: Yaxchilan, Piedras Negras and Pomona, Sourcebook for the XXXI Maya Meetings at Texas. Austin: University of Texas, Department of Art and Art History, Mesoamerica Center.

Stuart, David

2007c "The Origin of Copan's Founder”, Maya Decipherment. A Weblog on the Ancient MayaScript, June 25 ${ }^{\text {th }}, 2007$ < http://decipherment.wordpress.com/2007/06/25/ the-origin-of-copans-founder/>. [Retrieved April 13, 2011.]

Stuart, David and Stephen D. Houston

1994 Classic Maya Place Names. Washington DC: Dumbarton Oaks (Studies in Precolumbian Art and Archaeology, 33).

Tate, Carolyn

1992 Yaxchilan: A Design of a Maya Ceremonial City. Austin: University of Texas Press.

Tokovinine, Alexander

2006 "People from a Place: Reinterpreting Classic Maya Emblem Glyphs". Paper presented at the 11th European Maya Conference Ecology, Power, and Religion in Maya Landscapes. Malmö University, Sweden, December 4-9, 2006.

2007a "Of Snake Kings and Cannibals: A Fresh Look at the Naranjo Hieroglyphic Stairway”, PARI Journal, II (4): 15-22. San Francisco: Pre-Columbian Art Research Institute.

2007b "Classic Maya Place Name Database Project, Mesoamerica" < http://www. famsi.org/reports/06054/index.html > . [Retrieved April 13, 2011.]

Tokovinine, Alexander and Vilma Fialko

2007 "Stela 45 of Naranjo and the Early Classic Lords of Sa'aal", PARI Journal, II (4): 1-14. San Francisco: Pre-Columbian Art Research Institute.

Wagner, Elizabeth

2005 "Ranked Spaces, Ranked Identities: A View from Late Classic Copán on Local Hierarchies, Community Boundaries, and the Question of an Emic No- 
tion of the Maya Cultural Sphere", Maya Ethnicity - The Construction of Ethnic Identity from the Preclassic to Modern Times. Pierre R. Colas, Geneviève LeFort and Bodil Liljefors Persson (eds.). Markt Schwaben [Germany]: Verlag Anton Saurwein, 143-164.

WAYEB Drawing Archive

<http://www.wayeb.org/resourceslinks/wayeb_drawings.php $>$. [Retrieved April 13, 2011.]

Zender, Marc

2002

"The Toponyms of El Cayo, Piedras Negras and La Mar", Heart of Creation: The Mesoamerican World and the Legacy of Linda Schele. Andrea Stone (ed.). London: University of Alabama Press, 166-184. 